\title{
RANCANG BANGUN IGC (INDUCTION GENERATOR CONTROLLER) SEBAGAI REGULATOR FREKUENSI PADA GENERATOR INDUKSI 3 FASA 5 KW
}

\author{
Aceng Daud, Ahmad Deni Mulyadi, Apip Pudin \\ Jurusan Teknik Konversi Energi, Politeknik Negeri Bandung \\ Email : daud polban ayahoo.com
}

\begin{abstract}
Abstrak
PLTMH (Pembangkit Listrik Tenaga Mikro Hidro) merupakan pembangkit listrik alternatif yang memanfaatkan aliran air sungai atau aliran irigasi sebagai sumber tenaga. Generator yang digunakan PLTMH bermacam-macam, salah satunya adalah dengan menggunakan motor induksi sebagai generator atau IMAG (Induction Motor as Asyncronous Generator). PLTMH yang menggunakan motor induksi sebagai generator memiliki kelemahan yaitu tegangan dan frekuensinya akan berubah ketika terjadi perubahan pada beban. Untuk mengatasi hal tersebut maka dibutuhkan sebuah IGC (Induction Generator Controller).

Bagian utama dari IGC ini terdiri dari panel kontrol dan ballast load. Prinsip pengaturannya adalah menyeimbangkan antara daya yang dihasilkan oleh generator dengan beban (daya) konsumen. Pada saat beban konsumen berkurang, kelebihan daya yang dihasilkan generator akan dipindahkan ke ballast load sehingga beban total pada generator tidak berubah. Dari hasil percobaan, IGC yang telah dibuat mampu menstabilkan frekuensi generator induksi di $50 \mathrm{~Hz} \pm 1 \%$ ketika terjadi perubahan daya di beban utama dari $0 \mathrm{~kW}$ sampai 4.25 $k W$.
\end{abstract}

Kata kunci: Kontrol Frekuensi, Generator Induksi.

\section{PENDAHULUAN}

Di era globalisasi saat ini, manusia tidak terlepas dengan keberadaan energi listrik. Hampir semua aktivitas yang dilakukan menggunakan energi listrik, bahkan energi listrik menjadi penunjang utama dari terlaksananya suatu kegiatan. Banyaknya peralatan-peralatan elektronik yang semakin modern membutuhkan pasokan energi listrik yang tidak sedikit, sehingga beban yang ditanggung oleh sebuah pembangkit menjadi besar.

Pembangkitan energi listrik umumnya dilakukan dengan cara memutar generator sinkron [1] yang dikopel langsung dengan turbin atau mesin-mesin termal (Bensin dan Diesel) untuk menghasilkan energi listrik dengan tegangan bolak balik tiga fasa. Jika dilihat dari segi ekonomi, sistem semacam ini akan membutuhkan biaya yang besar dan penggunaannya untuk kapasitas pembangkitan yang besar pula. Untuk memenuhi kebutuhan energi listrik di daerah-daerah terpencil dengan kemampuan ekonomi masyarakat terbatas dan keperluan daya yang relatif rendah, salah satu alternatif yang dapat dilakukan adalah menggunakan motor induksi satu fasa sebagai penghasil energi listrik (generator induksi) yang dikopel dengan turbin atau mesin termal sebagai penggerak mulanya. Sebagai contoh, motor induksi yang digunakan pada pompa-pompa air rumah tangga dapat digunakan sebagai generator. Pada penelitian ini akan dilakukan rancang bangun IGC (Induction Generator Controller) sebagai regulator frekuensi. Hasil rancangan ditujukan untuk generator induksi 3 fasa $5 \mathrm{KW}$.

\section{TINJAUAN PUSTAKA}

Motor induksi dapat digunakan sebagai generator induksi dengan cara memutar rotor diatas putaran medan stator atau bekerja pada slip negatif (diatas putaran yang ada pada nameplate) [2]. Agar generator induksi dapat menghasilkan tegangan, syarat lain yang diperlukan adalah adanya arus eksitasi. Namun generator jenis ini mempunyai kelemahan, yaitu tegangan dan frekuensinya berubah-ubah jika terjadi perubahan beban. Oleh karena itu diperlukan suatu alat yang dapat mengatur tegangan dan frekuensi pada generator induksi. Bagian utama dari alat ini terdari dari panel kontrol dan ballast load. Prinsip pengaturannya adalah menyeimbangkan antara daya yang dihasilkan oleh generator dengan beban (daya) konsumen. Pada saat beban konsumen berkurang, kelebihan daya yang dihasilkan generator akan dipindahkan ke ballast load 
sehingga beban total pada generator tidak berubah.

Kurva karakteristik Kopel - Kecepatan mesin induksi untuk berbagai mode operasi terlihat pada Gambar 1 berikut [3];

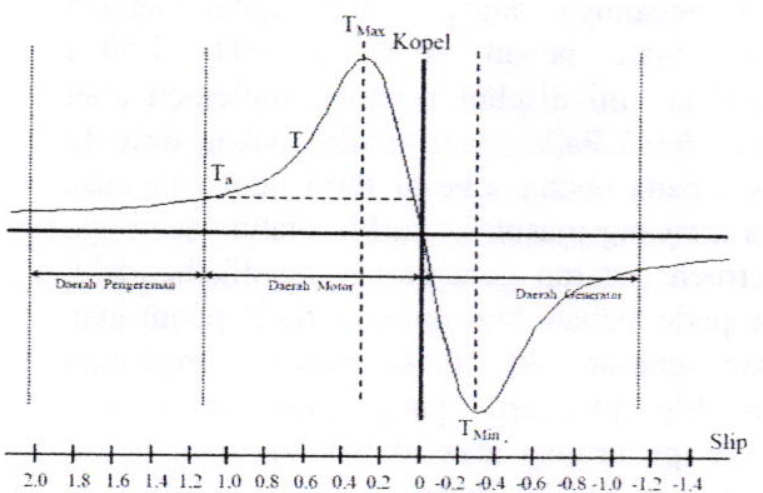

Gambar 1. Kurva Karakteristik Kopel - Selip

Jika pada lengkung kopel-putaran, kopel dan putaran mempunyai tanda yang berlawanan sehingga perkalian kopel nominal, Tn dan putaran menjadi negatif, maka mesin induksi bekerja sebagai generator. Yang akan diperhatikan adalah harga kopel $\mathrm{T}$ negatif dan putaran positif, jadi pada slip negatif. Itu artinya motor induksi diputar melebihi kecepatan sinkronnya [4].

Pada motor induksi, kecepatan putaran rotor $\left(n_{\mathrm{r}}\right)$ selalu lebih kecil dari kecepatan sinkron $\left(\mathrm{n}_{\mathrm{s}}\right)$. tetapi pada generator induksi, kecepatan putaran rotor $\left(\mathrm{n}_{\mathrm{r}}\right)$ harus dibuat lebih besar dari kecepatan sinkron $\left(n_{s}\right)$ sehingga energi listrik akan dikembalikan pada sistem jala-jala. Slip pada generator induksi selalu dalam harga negatif. Hal ini dapat dilihat dari persamaan berikut;

$$
S=\left(\frac{n_{s}-n_{\tau}}{n_{s}}\right)
$$

Jika $n_{r}>n_{s}$, maka harga $S$ menjadi negatif.

Hubungan frekuensi dengan slip dapat dilihat sebagai berikut;

Bila $f 1=$ frekuensi jala-jala, $n s=\frac{120 f}{p}$ atau $f 1=\frac{P n_{s}}{120}$ pada rotor berlaku hubungan:

frekuensi arus rotor $=f 2=\frac{p\left(n_{5}-n_{t}\right)}{120}$..

Atau

$$
f 2=\frac{p n_{5}}{120} x \frac{\left(n_{5}-n_{7}\right)}{n_{5}}
$$

Karena

$$
S=\left(\frac{n_{s}-n_{r}}{n_{s}}\right) \text { dan } f 1=\frac{p n_{s}}{120}
$$

Maka,

$$
f 2=f 1 \times S \text {. }
$$

Daya reaktif atau daya magnetisasi dibutuhkan untuk membangkitkan tegangan pada terminal keluarannya [5]. Dalam hali ini yang berfungsi sebagai penyedia daya reaktif adalah kapasitor yang besarnya disesuaikan dengan daya reaktif yang diperlukan. Besarnya kapasitor dapat ditentukan dengan persamaan berikut :

$$
\begin{aligned}
& x_{c}=\frac{V_{n}}{I_{b}} \ldots . \\
& c=\frac{1}{2 \pi f x_{c}} .
\end{aligned}
$$

dimana:

- $\quad \mathrm{Vn}=$ tegangan nominal

- $\quad \mathrm{Ib}=$ arus buta

- $\mathrm{Xc}=$ reaktansi yang diperlukan untuk menyediakan arus buta

- $\mathrm{C}=$ kapasitor yang diperlukan untuk menyediakan arus buta

- $\mathrm{F}$ = frekuensi

Kebutuhan daya reaktif dapat dipenuhi dengan memasang suatu unit kapasitor pada terminal keluaran. Dimana kapasitor memberikan daya reaktif pada mesin induksi. Kerja dari kapasitor ini dapat dipandang sebagai suatu sistem penguat (eksitasi), sehingga generator induksi juga dikenal dengan sebutan generator induksi penguatan sendiri (self excited induction generator).

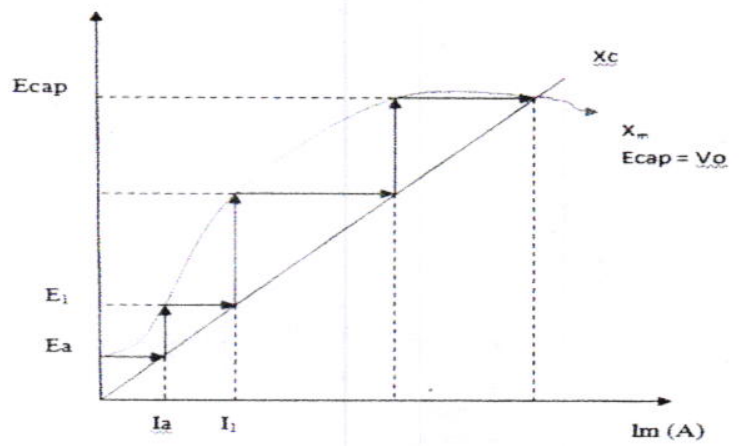

Gambar 2. Proses Pembangkitan Tegangan Pada Generator Induksi

Proses eksitasi sendiri pada generator induksi adalah adanya fluksi sisa atau medan 
magnet pada kumparan stator. Tegangan induksi akan terinduksi pula pada sisi stator dan akan menimbulkan arus yang akan mengisi kapasitor hingga terjadi keseimbangan. Keseimbangan tersebut ditandai dengan titik pertemuan antara lengkung magnetisasi dengan garis reaktansi kapasitif seperti terlihat pada gambar 2 . Lengkung magnetisasi tersebut terjadi akibat adanya kejenuhan inti besi dari mesin.

Penggunaan generator induksi pada kondisi stand alone mempunyai kelemahan yaitu tegangan dan frekuensi keluaran generator akan berubah ketika terjadi perubahan beban, hal ini terlihat pada grafik karakteristik generator induksi pada gambar 3, ketika beban berkurang kecepata bertambah dan akibatnya frekuensi berubah.

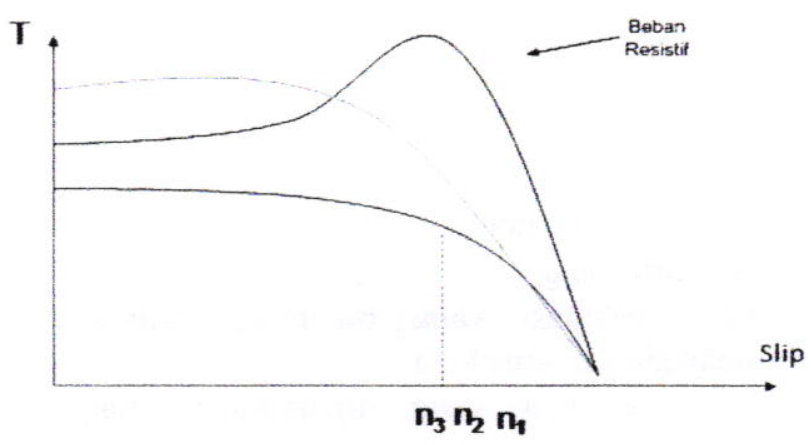

Gambar 3. Karakteristik Generator Induksi

Untuk mengatasi hal tersebut, maka diperlukan adanya IGC sebagai pengendali frekuensi [6]. Pengendalian frekuensi dimaksudkan untuk mengendalikan putaran (frekuensi) generator sehingga pengendalian putaran dalam PLTMH diutamakan berfungsi sebagai pengendali frekuensi generator. Jika daya air yang masuk ke turbin dibuat selalu konstan sehingga daya penggerak turbin selalu konstan, maka frekuensi dan respon generator akan menjadi fungsi beban. Agar frekuensi yang dihasilkan oleh generator selalu konstan, maka besar beban dari generator harus selalu konstan. Untuk itu diperlukan beban tambahan yang besar bebannya dapat diatur sesuai dengan pengurangan beban dari PLTMH. Beban tambahan ini disebut beban komplemen atau ballast load. Pada suatu kondisi beban tertentu (misal pada beban sebesar $80 \%$ beban penuh), daya air yang masuk ke turbin diatur sehingga diperoleh putaran generator yang dikehendaki. Jika pada beban konsumen terjadi penurunan beban sebesar $\Delta \mathrm{L}$, maka beban komplemen akan dilewati arus yang rata-ratanya akan sebesar penurunan arus akibat turunnya beban konsumen $(\Delta \mathrm{L})$ sehingga generator akan dibebani dengan total beban yang selalu konstan. Diagram blok dari uraian tersebut ditunjukkan pada Gambar 4.

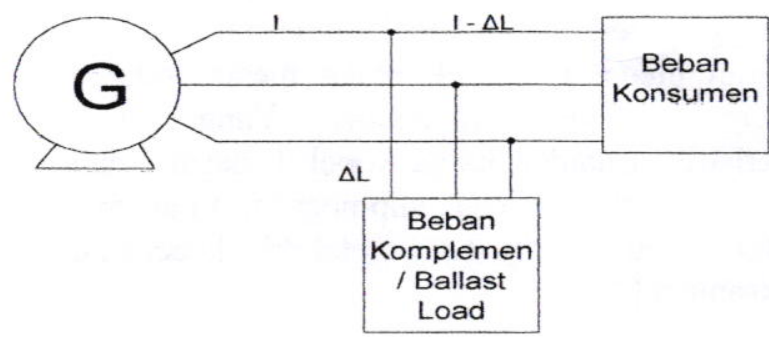

Gambar 4. Blok diagram pembagian beban komplemen

Daya yang masuk ke turbin dibuat konstan sehingga beban yang dirasakan oleh generator juga selalu konstan, maka putaran generator juga akan konstan. Jika debit air konstan, maka generator harus dibebani dengan daya yang konstan agar putaran generator selalu konstan.

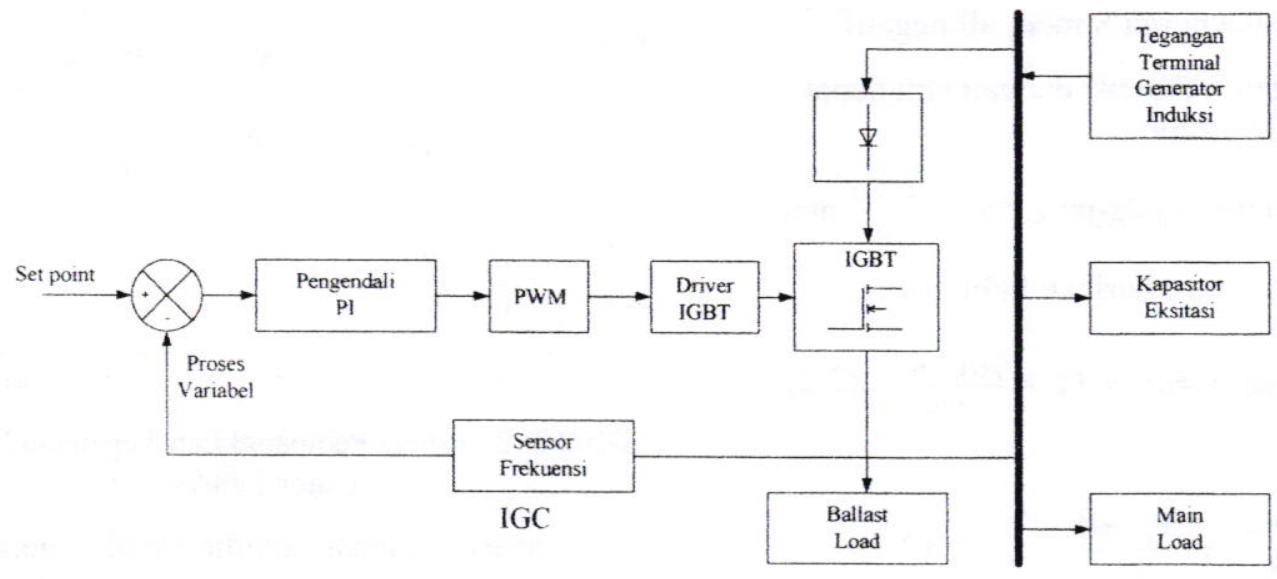

Gambar 5. Blok Diagram Pengendalian Frekuensi Generator Induksi 
Beban konsumen tidak selalu konstan, maka untuk menjaga kestabilan putaran turbin generator diperlukan beban komplemen yang besarnya diatur oleh IGC. Persamaan pengaturan beban oleh IGC, sebagai berikut :

Kapasitas Nominal Generator = Beban Konsumen + Beban Komplemen

\section{PERANCANGAN ALAT}

Untuk mempermudah pemahaman mengenai prinsip kerja pengendali frekuensi Generator induksi maka terlebih dahulu mengetahui sistem kerja dari blok diagram kontrol pada gambar 5. Pada set-point diberikan sesuai dengan keinginan frekuensi yang kita inginkan, perintah yang diberikan pada pengendali analog berupa tegangan $(0-8$ volt $)$. Umpan balik dari sensor frekuensi merupakan proses variabel yang juga merupakan masukan bagi error detector $(0-8$ volt $)$. Keluaran dari error detector berupa tegangan yang akan diolah oleh pengendali $(0-8$ volt $)$. Keluaran dari pengendali yang juga masih berupa tegangan akan memberikan masukan bagi rangkaian pembangkit pulsa (rangkaian pulse width modulation) yang dapat mempengaruhi besar kecilnya dutty cycle.

Keluaran dari rangkaian pembangkit pulsa merupakan pulsa yang kemudian dikuatkan oleh rangkaian Driver IGBT. Kemudian keluaran dari Driver IGBT merupakan pulsa yang telah dikuatkan yang dapat mengatur waktu pensaklaran IGBT sehingga tegangan keluarannya dapat terkontrol dan diberikan pada ballast load. Hal ini akan membawa akibat pada perubahan frekuensi generator induksi.

\section{Rangkaian $\boldsymbol{F}$ to $\boldsymbol{V}$ Converter}

Rangkaian $F$ to $V$ Converter merupakan rangkaian yang berfungsi sebagai pengubah frekuensi menjadi tegangan. Rangkaian ini dirancang dengan menggunakan IC LM 2917N.

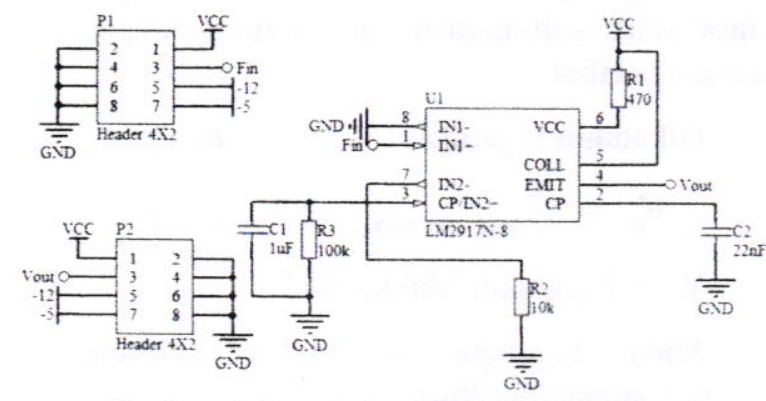

Gambar 6. Rangkaian F to V Converter
Frekuensi dideteksi melalui gelombang sinusoida AC yang masuk ke pin 1 yang kemudian gelombang tersebut di rubah menjadi gelombang kotak yang kemudian disearahkan. Untuk mengatur kelinieran perubahan tegangan output maka aturlah besarnya $\mathrm{R}_{3}$ dan $\mathrm{C}_{1}$. Untuk lebih jelasnya lihat gambar 6 .

Rangkaian ini mempunyai batas input frekuensi dari $10-10 \mathrm{kHz}$ dengan tegangan pembawa sebesar $6 \mathrm{~V}$ AC. Besar kecilnya output frekuensi. Frekuensi yang dideteksi pada perancangan ini berkisar antara $45-55 \mathrm{~Hz}$ dengan tegangan output sebesar $0.72-0.89$ volt.

\section{Rangkaian Span Zero}

Rangkaian span zero, gambar 7. dirancang untuk memenuhi kebutuhan dari rangkaian kendali PI karena keluaran dari rangkaian $F$ to $V$ Converter tidak sesuai dengan yang dibutuhkan rangkaian pengendali PI yang membutuhkan masukan tegangan sebesar $0-8$ volt.

Pada saat keluaran tegangan dari $F$ to $V$ Converter sebesar 0 volt, input tegangan yang dibutuhkan rangkaian pengendali PI adalah sebesar 8 volt. Sedangkan pada saat output $F$ to $V$ Converter sebesar 0.82 volt, input tegangan yang dibutuhkan oleh aktuator adalah 0 volt.

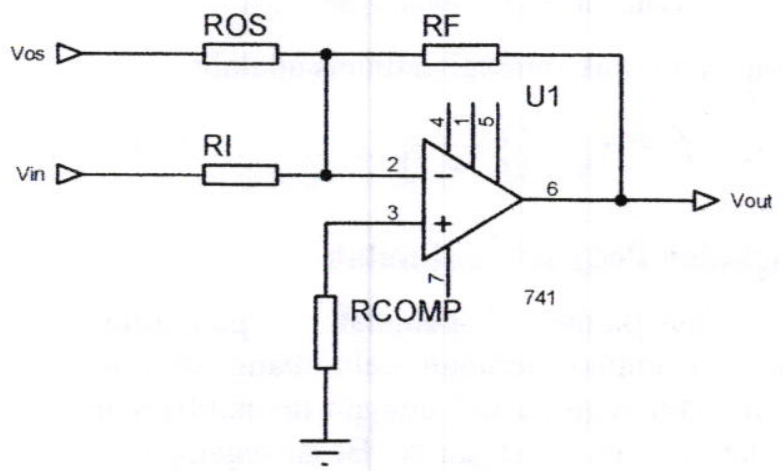

Gambar 7. Rangkaian Span Zero

Persamaan untuk rangkaian diatas adalah

$$
V_{o u t}=-\left(\frac{R_{f}}{R_{i}} V_{i n}+\frac{R_{f}}{R_{o s}} V_{o s}\right) \ldots
$$

Jika nilai $R_{\mathrm{f}}$ dipastikan sebesar $330 \mathrm{k} \Omega$ dan $V_{o s}$ $=-5$ volt.

$\mathrm{R}_{\mathrm{i}}$ yang dipilih $\mathrm{R}=20 \mathrm{k} \Omega$ dan potensiometer $=20 \mathrm{k} \Omega$

$$
\frac{1}{R_{\text {Comp }}}=\frac{1}{R_{f}}+\frac{1}{R_{o s}}+\frac{1}{R_{i}}
$$




\section{Rangkaian Pembangkit Gelombang Segitiga}

Rangkaian pembangkit pulsa dirancang untuk memberikan keluaran berupa gelombang segitiga ac yang kemudian akan dibandingkan oleh rangkaian komparator setelah dirubah dari gelombang segitiga ac menjadi segitiga dc oleh rangkaian penguat penjumlah.

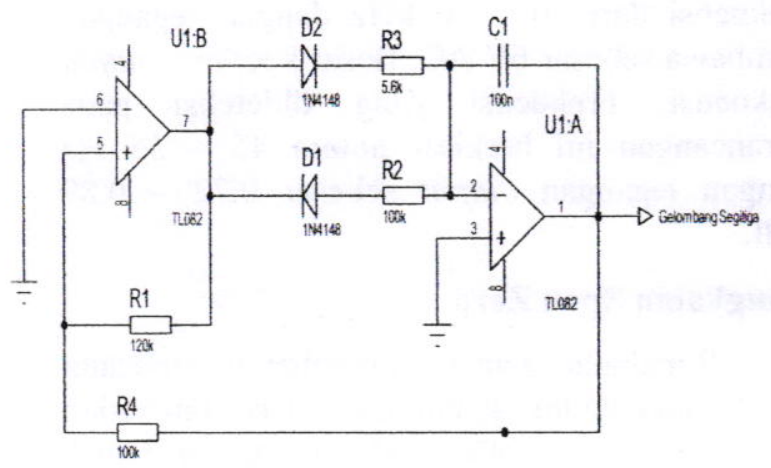

Gambar 8. Rangkaian Pembangkit Gelombang Segitiga

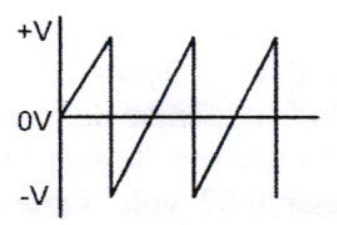

Gambar 9. Gelombang Segitiga

Persamaan untuk rangkaian diatas adalah;

$$
f=\frac{R_{\mathrm{g}}}{\left(2 C R_{4}\left(R_{1}+R_{\mathbf{2}}\right)\right)}
$$

\section{Rangkaian Penguat Penjumlah}

Rangkaian penguat penjumlah dirancang untuk merubah gelombang segitiga AC menjadi segitiga DC dengan menambahkan masukan berupa tegangan dc. Besar tegangan dc yang dimasukkan sebesar tegangan dari titik negatif menuju titik nol. Untuk lebih jelasnya lihat pada gambar 10 .

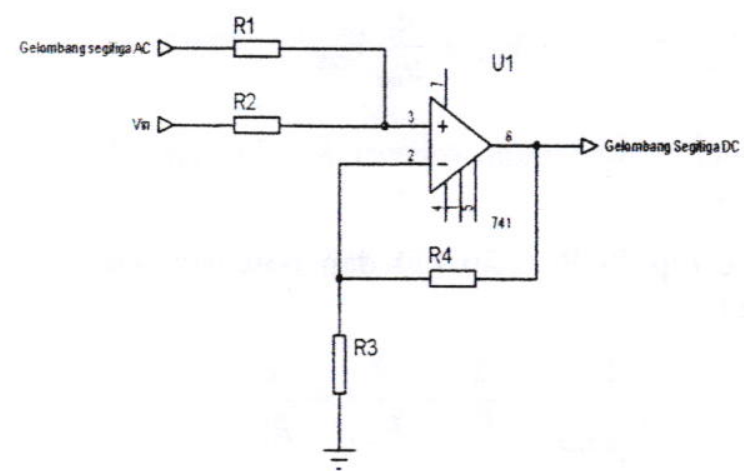

Gambar 10. Rangkaian Penguat Penjumlah
Persamaan dari rangkaian diatas adalah :

$$
V_{\text {out }}=\left(1+\frac{R_{\mathrm{s}}}{R_{\mathrm{s}}}\right) x\left(V_{\text {in } 1}+V_{\text {in } 2}\right)
$$

\section{Rangkaian Komparator}

Rangkaian komparator dirancang untuk membandingkan antara gelombang segitiga dengan tegangan DC, keluaran dari komparator berupa pulsa yang akan digunakan untuk trigger pensaklaran IGBT/MOSFET.

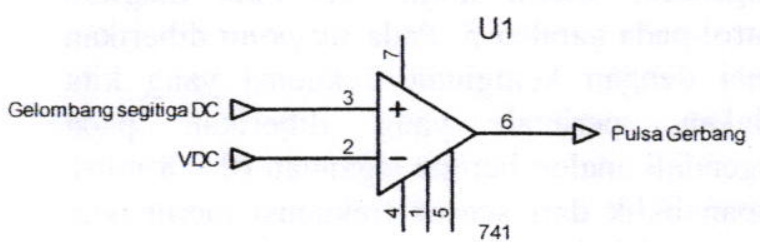

Gambar 11. Rangkaian Komparator

\section{Rangkaian Penyearah Jembatan 3 Fasa}

Rangkaian Penyearah Jembatan 3 Fasa dirancang sebagai penyearah tegangan ac 3 fasa menjadi tegangan dc. Besar tegangan dc dapat dihitung dengan persamaan 3.5.

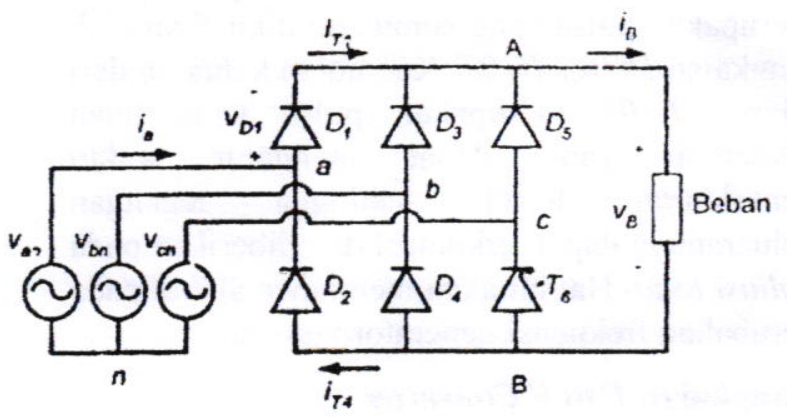

Gambar 12. Rangkaian Penyearah Jembatan 3 Fasa

Pemilihan IGBT ditentukan dengan cara menghitung tegangan dc input yang akan dikontrol, tegangan $\mathrm{dc}$ ini berasal dari tegangan tiga fasa $380 \mathrm{~V}$ sehingga dapat dihitung dengan persamaan berikut:

Diketahui tegangan $\mathrm{V}_{\text {line-line }}=380 \mathrm{~V}$,

$$
V_{m}=V_{\text {line-Netral }} x \sqrt{2} \text {. }
$$

$\mathrm{V}_{\mathrm{m}}=$ Tegangan Maksimal

Maka tegangan dc dapat dihitung dengan persamaan berikut;

$$
V_{D C}=V_{m} \frac{3 \sqrt{3}}{\pi}
$$


Maka IGBT yang dipilih adalah IGBT yang mampu beroperasi pada tegangan diatas $513.18 \mathrm{~V}$. dari datasheet IGBT yang beroperasi pada tegangan diatas $513.18 \mathrm{~V}$ memerlukan tegangan gate $\left(\mathrm{V}_{\mathrm{GE}}\right)$ lebih dari samadengan 15 $\mathrm{V}$. sedangkan tegangan gate dari keluaran rangkaian pembangkit pulsa gerbang sebesar 11.26 V. Maka diperluakan rangkaian Driver IGBT supaya kebutuhan $V_{\mathrm{GE}}$ IGBT $15 \mathrm{~V}$ terpenuhi.

\section{Rangkaian Driver IGBT}

Rangkaian driver IGBT dirancang dengan menggunakan optoisolator TLP250 bertujuan untuk memenuhi kebutuhan tegangan gate IGBT yaitu sebesar 15 volt dan sebagai pemisah antara rangkaian kontrol dengan rangkaian daya. Suplai tegangan rangkaian ini terpisah dengan rangkaian kontrol.

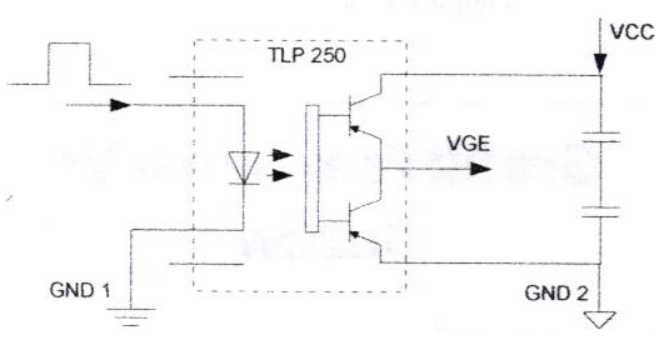

Gambar 13. Rangkaian Driver IGBT

\section{Rangkaian DC Controller}

Rangkaian $D C$ controller dirancang sebagai penyuplai daya pada ballast load. Besar kecilnya tegangan keluaran tergantung dari duty cycle yang pada tegangan gate yang diberikan pada IGBT.

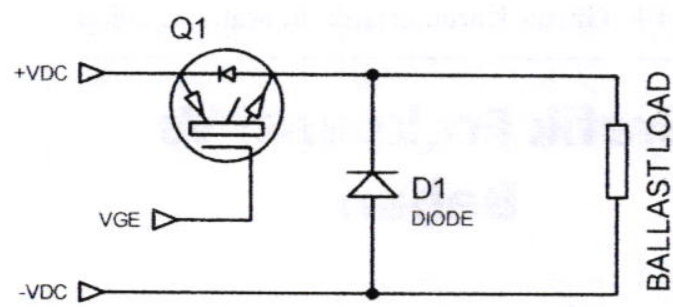

Gambar 14. Rangkaian DC Controller

\section{Rangkaian Error Detector}

Rangkaian ini dirancang dengan menggunakan IC LM 324. Rangkaian ini berfungsi untuk melakukan pengkoreksian terhadap proses variabel yang terjadi di objek pengendali yaitu berupa frekuensi generator induksi. Rangkaian yang digunakan adalah rangkaian penguat pembeda tegangan (difference amplifier) yang dilengkapi dengan rangkaian penyangga yang bertujuan untuk mencegah terjadinya drop tegagan masukan.

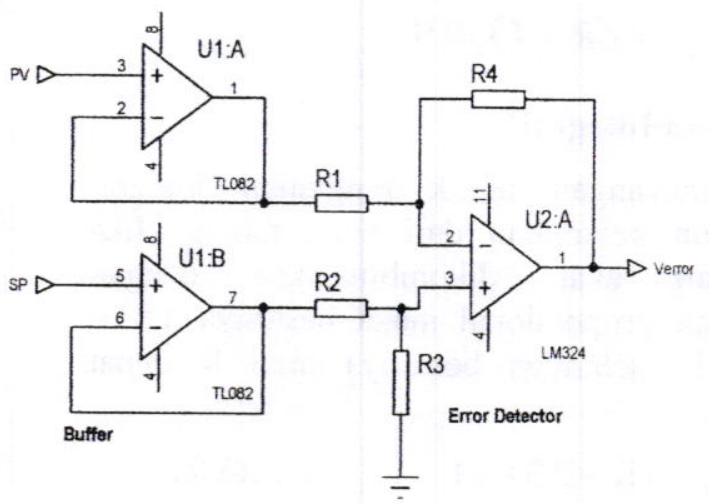

$\mathrm{Ga}$

Gambar 15. Rangkaian Buffer dan Error Detector

Persamaan rangkaian diatas adalah:

$$
V_{\text {out }}=\frac{R_{4}}{R_{1}}\left(V_{S P}-V_{P V}\right)
$$

Dimana:

$$
\mathrm{R}_{1}=\mathrm{R}_{2}=\mathrm{R}_{3}=\mathrm{R}_{4}=10 \mathrm{k} \Omega \text {. }
$$

\section{Rangkaian Proporsional}

Perancangan rangkaian proporsional terlebih dahulu melakukan tuning dengan menggunakan metoda kurva reaksi. Perhitungan untuk menentukan nilai PB dan TR adalah sebagai berikut:

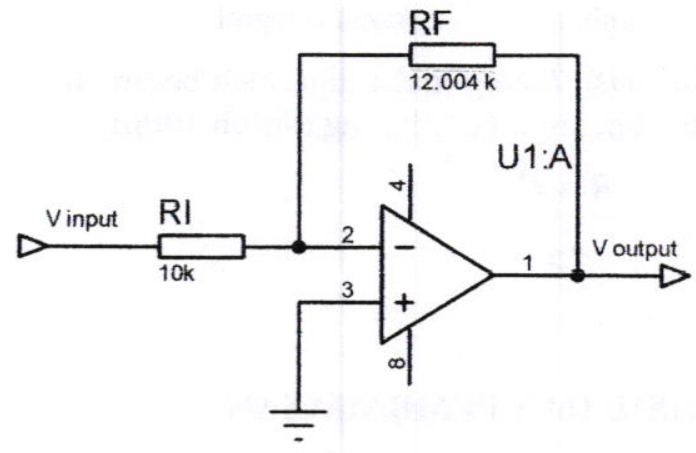

Gambar 16. Rangkaian Proporsional

Skala pada pengujian untuk tunning

$\mathrm{T}=1 \mathrm{detik} / \mathrm{cm}$

$\mathrm{V}=1 \mathrm{~V} / \mathrm{cm}$

Perubahan set point $=5$ volt -4.26 volt .

Persentase kenaikan set point

$$
=\frac{5-4.26}{5} \times 100 \%=14.8 \%
$$

$$
\begin{aligned}
& \mathrm{A}=0.8 \text { detik } \\
& \mathrm{B}=0.74 \text { Volt } \\
& \mathrm{L}=0.8 \text { detik } \\
& \mathrm{R}=\mathrm{B} / \mathrm{A}
\end{aligned}
$$


Nilai PB dan TR pengendali proporsional dan integral

$$
P_{B}=(R \times L) / 0.9
$$

\section{Rangkaian Integral}

Perancangan untuk rangkaian integral merupakan kelanjutan dari hasil tuning. Jika pengendali akan dikombinasikan dengan pengendali proporsional maka besarnya TR = $3.33 \times \mathrm{L}$. sehingga besarnya nilai $\mathrm{R}$ dapat dihitung.

$$
\mathrm{TR}=3.33 \times \mathrm{L}
$$

Besarnya nilai TR akan menentukan lamanya waktu dalam merespon terhadap suatu masukan. IC yang digunakan pada pengendali integral adalah TL084.

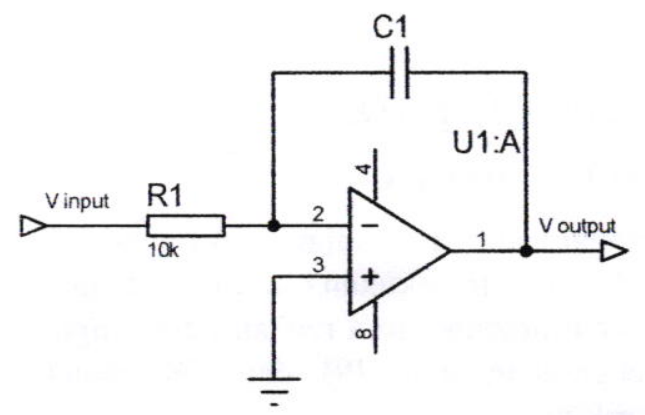

Gambar 17. Rangkaian Integral

Dari hasil tuning maka diperoleh besarnya $\mathrm{TR}=2.664$ dengan nilai $\mathrm{C} 1$ yang dipilih $100 \mu \mathrm{f}$.

$$
T_{R}=\frac{R \times C}{K_{p}}
$$

\section{HASIL DAN PEMBAHASAN}

Motor induksi yang digunakan dalam penelitian ini adalah:

3 Phase Squirrel Cage Asyncronous Motor

Type $=$ DL2030/s $\quad n^{\circ}=068702$

Supply Voltage $=220 / 380 \mathrm{~V}$

Rated Current $=20.8 / 12 \mathrm{~A}$

Rated Power $=5.5 \mathrm{~kW}$

Rated Speed $=2900 \mathrm{rpm}$

Frequency $=50 \mathrm{~Hz}$

Insulation $=\mathrm{F}$

$\operatorname{Cos} \theta=0.89$
Karakterisik generator induksi yang didapat melalui percobaan didapatkan seperti ditunjukan pada Gambar 18.

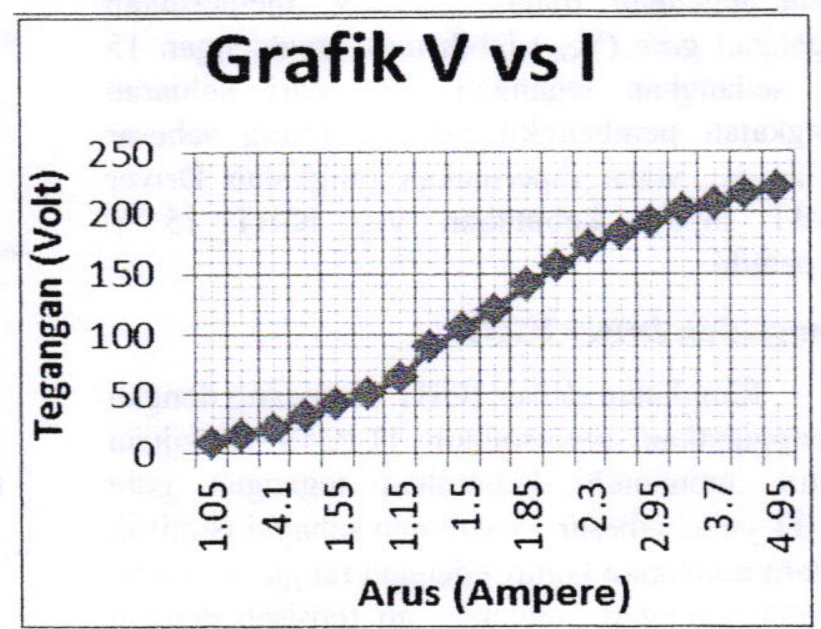

Gambar 18. Grafik Karakteristik Motor Induksi Tanpa Beban

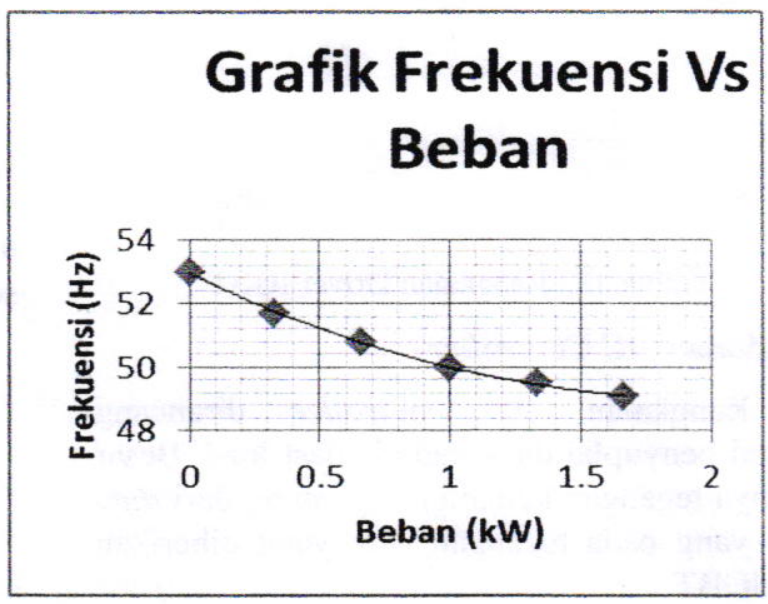

Gambar 19. Grafik Karakteristik Genrator Induksi

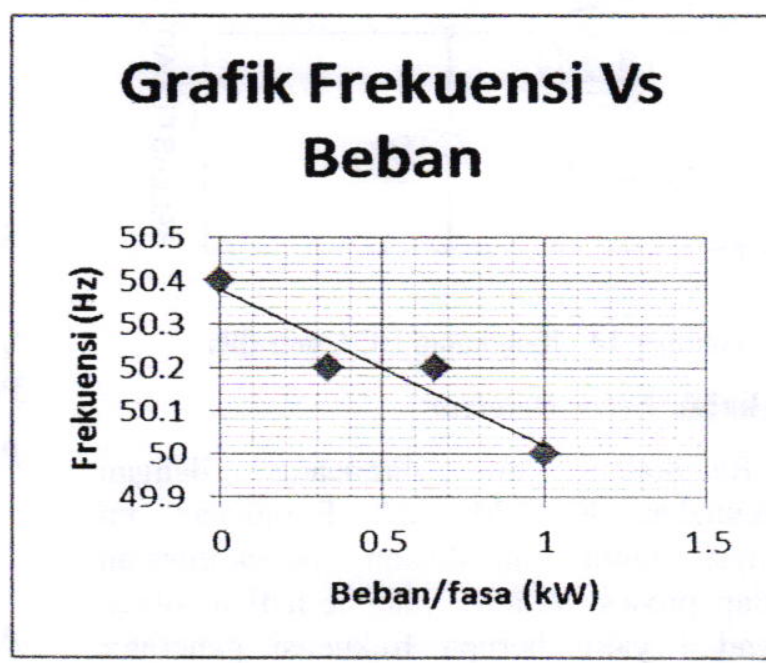

Gambar 20.1 Grafik Karakteristik Generator dengan menggunakan IG 
Dari karakteristik tersebut di atas, maka nilai kapasitansi sesuai dengan Persamaan 2.6 dan 2.7 didaptkan sebesar $71.6 \mu \mathrm{F}$.

Karakteristik pembebanan generator indksi tanpa IGC ditunujkan pada Gambar 19. Dari grafik di atas, terlihat bahwa frekuensi genaror menurun terhadap peningkatan beban.

Karakteristik pembebanan generator induksi dengan IGC diperlihatkan pada Gambar 20.

Pada grafik diatas terlihat bahwa perubahan frekuensi terjadi pada batasan yang diinginkan yaitu sekitar $50 \mathrm{~Hz} \pm 1 \%$. Ketika beban turun dari $2.68 \mathrm{~kW}$ sampai $1.84 \mathrm{~kW}$ frekuensi naik dari $50 \mathrm{~Hz}$ sampai $50.2 \mathrm{~Hz}$. IGC optimal ketika terjadi penurunan beban dari 1.84 $\mathrm{kW}$ sampai $1.28 \mathrm{~kW}$, karena frekuensi tetap pada $50.2 \mathrm{~Hz}$. Hal ini disebabkan terjadi pengalihan daya lebih yang seimbang dari generator yang semula menuju beban utama (Main Load) menjadi beralih ke - beban komplemen (Ballast Load).

Karakteristik generaor induksi dengan dan tanpa menggunakan IGC diperlihatkan pada Gambar 21. di bawah

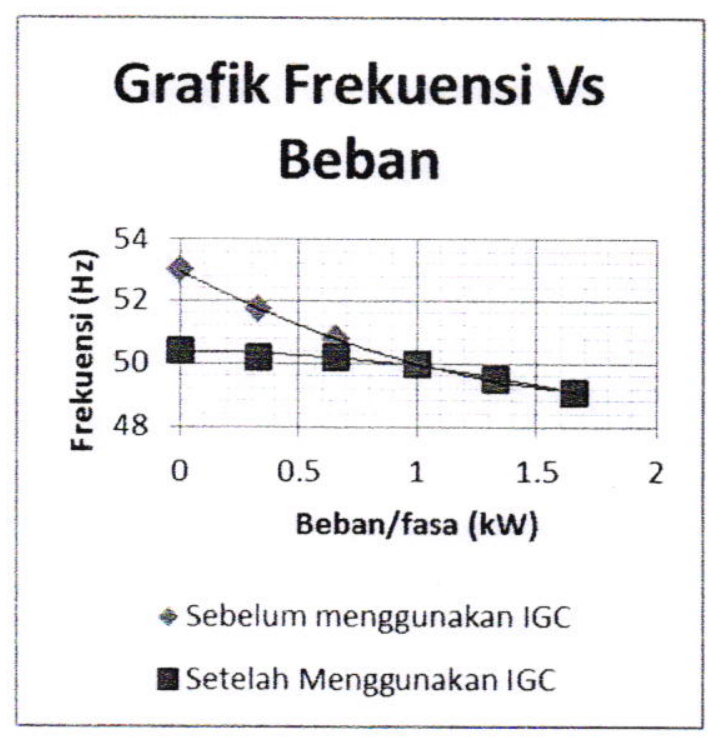

Gambar 21. Grafik Karakteristik Generator dengan dan tanpa Menggunakan IGC

Berdasarkan grafik diatas terbukti bahwa dengan adanya IGC frekuensi keluaran generator relatif konstan walaupun terjadi perubahan beban. Untuk lebih jelasnya dapat dilihat pada gambar 22. Pada grafik pembebanan generator diatas, dapat dilihat bahwa ketika beban utama dalam keadaan nol, beban komplemen berada dititik puncak (maksimal) sedang kan ketika beban utama maksimal maka daya pada beban komplemen sama dengan nol. Hal ini terbukti dengan hasil perhitungan dari data yang diperoleh bahwa ketika terjadi perubahan daya pada beban utama dan beban komplemen selalu terjadi keseimbangan yaitu daya keluaran generator relatif konstan sebesar $2.65 \mathrm{~kW}$.

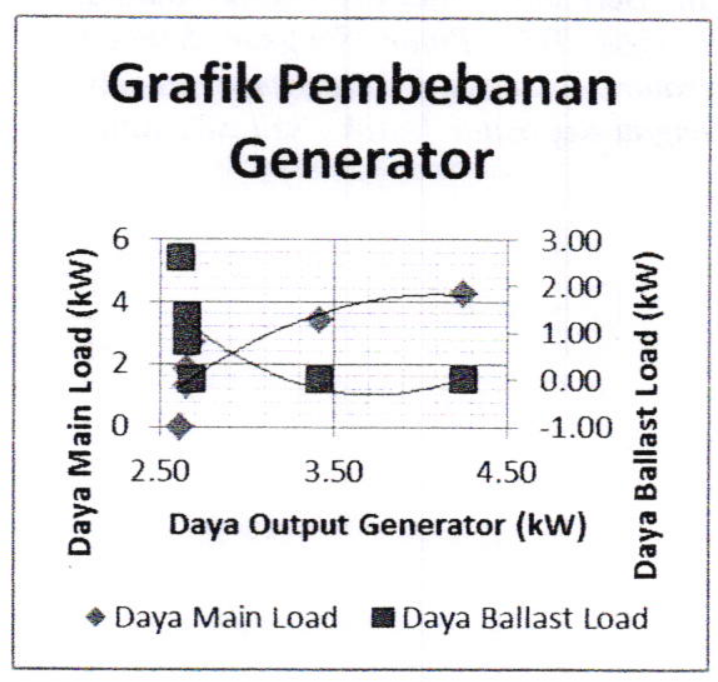

Gambar 22. Daya Pembebanan pada Generator

\section{KESIMPULAN}

Perubahan beban sangat berpengaruh terhadap perubahan frekuensi generator penggunaan IGC mampu mengatasi perubahan frekuensi tersebut. Ketika beban bertambah maka IGC akan berusaha untuk menyeimbangkan beban sehingga berpengaruh pada frekuensi generator. Frekuensi stabil di 50 $\mathrm{Hz} \pm 1 \%$. Rangkaian kontrol IGC mampu mempertahankan frekuensi sampai generator menghasilkan daya sebesar $4.25 \mathrm{~kW}$ sedangkan harapannya di $5.5 \mathrm{~kW}$, ini terjadi karena generator yang digunakan berasal dari motor induksi $5.5 \mathrm{~kW}$ sehingga terjadi rugi-rugi dan yang tercapai hanya $4.25 \mathrm{~kW}$.

\section{PUSTAKA}

[1] Djiteng Marsudi, "Pembangkitan Energi Listrik", Erlangga Jakarta, 2005

[2] Machmud Effendy, "Rancang Bangun Motor Induksi Sebagai Generator (Misg) Pada Pembangkit Listrik Tenaga Mikrohidro", TRANSMISI Jurnal Teknik Elektro, Volume 11, Nomor 2, Juni 2009, hlm. 71-76

[3] Chairul Gagarin Irianto, "Suatu Studi Penggunaan Motor Induksi sebagai Generator: Penentuan Nilai Kapasitor Untuk 
Penyedia Daya Reaktip", JETri, Volume 3, Nomor 2, Februari 2004, Halaman 1-16, ISSN 1412-0372

[4] Djoekardi, Djuhana, "Mesin-mesin Listrik Motor Induksi" Universitas Trisakti, Jakarta, 1996

[5] Rahmi Berlianti, "Analisis Motor Induksi Fasa Tiga Tipe Rotor Sangkar Sebagai Generator Induksi Dengan Variasi Hubungan Kapasitor Untuk Eksitasi", Jurnal
Nasional Teknik Elektro, Vol: 4, No. 1, Maret 2015 ISSN: 2302 - 2949

[6] Ana Ningsih, Oyas Wahyunggoro, M Isnaeni BS, "Kendali Penstabil Frekuensi Dan Tegangan Untuk Pembangkit Listrik Mikrohidro Menggunakan Beban Komplemen Dengan Pengendali Pid Dan $P w m^{\prime \prime}$, Seminar Nasional ke - 9: Rekayasa Teknologi Industri dan Informasi, Sekolah Tinggi Teknologi Nasional (STTNAS) Yogyakarta, hal. 85-90 